\title{
ORIGINAL ARTICLE \\ Activation of macrophage mediated host defense against Salmonella typhimurium by Morus alba L.
}

\author{
BoYoon Chang', BongSeong Koo², HyeonCheol Lee², Joa Sub Oh³, SungYeon Kim** \\ 'Institute of Pharmaceutical Research and Development, College of Pharmacy, Wonkwang University, Iksan, Jeonbuk, \\ South Korea; ${ }^{2}$ ForBioKorea Co., Ltd. Seoul, South Korea; ${ }^{3}$ College of Pharmacy, Dankook University, Cheonan, South \\ Korea
}

Abstract

Background: The innate immune system plays a crucial role in the initiation and subsequent direction of adaptive immune responses, as well as in the removal of pathogens that have been targeted by an adaptive immune response.

Objective: Morus alba L. was reported to have immunostimulatory properties that might protect against infectious diseases. However, this possibility has not yet been explored. The present study investigated the protective and immune-enhancing ability of $M$. alba L. against infectious disease and the mechanisms involved. Design: To investigate the immune-enhancing effects of $M$. alba L., we used a bacterial infection model.

Results and discussions: The lifespan of mice infected with a lethal dose of Salmonella typhimurium $\left(1 \times 10^{7}\right.$ colony forming units - CFU) was significantly extended when they were administered $M$. alba L. Furthermore, $M$. alba L. activated macrophages, monocytes, and neutrophils and induced Th1 cytokines (IL-12, IFN- $\gamma, \mathrm{TNF}-\alpha)$ in mice infected with a sublethal dose $\left(1 \times 10^{5} \mathrm{CFU}\right)$ of $S$. typhimurium. M. alba L. significantly stimulated the uptake of bacteria into peritoneal macrophages as indicated by increased phagocytosis. Peritoneal macrophages derived from $\mathrm{C} 3 \mathrm{H} / \mathrm{HeJ}$ mice significantly inhibited $M$. alba $\mathrm{L}$. induced NO production and $\mathrm{TNF}-\alpha$ secretion compared with peritoneal macrophages derived from $\mathrm{C} 3 \mathrm{H} / \mathrm{HeN}$ mice.

Conclusions: These results suggest that the innate immune activity of $M$. alba L. against bacterial infection in mice occurs through activation of the TLR4 signaling pathway.

Keywords: Morus alba L; TLR4; Salmonella; immune defense; macrophage

Received: 19 September 20 17; Revised: 30 November 20 I7; Accepted: 19 January 20 I8; Published: 21 February 2018

$\mathrm{B}$ acterial infectious agents are responsible for high morbidity and mortality in humans (1). Antibiotic drugs are used to combat these pathogens; however, the rise in antibiotic-resistant pathogens has led to the development of new therapeutic agents that are effective against these bacteria $(2,3)$.

The immune system is our natural defense system against pathogens such as viruses, bacteria, and other agents (4). It is composed of the innate immune system and the adaptive immune system. The innate immune system is a primary defense mechanism against invading organisms, while the adaptive immune system acts as a second line of defense. Both aspects of the immune system have cellular and humoral components that mediate their protective functions. Macrophages are the most abundant cells in granulomas and have been shown to play a key role throughout the course of infection in all infected hosts, including humans and non-human primates. Once these bacteria enter a host, Toll-like receptors (TLRs) recognize a variety of microbial products, including bacterial cell wall components and endocytosed nucleic acids, thereby triggering innate immune responses (5-7). Most laboratory studies have focused on the modulation of antimicrobial peptides and innate immune mediators by microbial components $(8,9)$. However, the effect of herbal plant extracts on immune responses to infectious diseases is not well established. An attempt has been made to identify a potent immunostimulator from plant extracts selected for their immune pharmacological properties. Our previous study showed that Morus alba L. had immunostimulatory effects in macrophages (10). In addition, M. alba L. might have an indirect anticancer effect by enhancing immune responses through TLR4 signaling (11). However, the protective effects of $M$. alba L. against pathogens have not been examined. In the present study, we investigated the protective effect and macrophage-mediated immune 
responses of $M$. alba L. in mice challenged with pathogenic Salmonella typhimurium.

\section{Materials and methods}

\section{Chemical and reagents}

Roswell Park Memorial Institute medium 1640 (RPMI) and fetal bovine serum (FBS) were obtained from GIBCO (Grand Island, NY, USA). A nitric oxide (NO) detection kit was obtained from INTRON Biotechnology (Sungnam, Korea). Trizol was obtained from Invitrogen (Carlsbad, CA, USA). Interleukin (IL) 6, IL-12, interferon gamma $(\mathrm{IFN}-\gamma)$ and tumor necrosis factor alpha (TNF- $\alpha$ ) were obtained from R\&D Systems (Minneapolis, MN, USA). Penicillin, streptomycin, neutral red, 3-(4,5-dimethylthiaz ol-2-yl)-2,5-diphenyltetrazolium bromide, lipopolysaccharide (LPS), and all other chemicals were obtained from Sigma-Aldrich (St. Louis, MO, USA).

\section{Cell culture and animal care}

Peritoneal macrophages were prepared from $B A L B / c$, $\mathrm{C} 3 \mathrm{H} / \mathrm{HeJ}$ (wild type) and $\mathrm{C} 3 \mathrm{H} / \mathrm{HeN}$ (TLR4 mutant) mice as described previously (12). RAW264.7 cells were routinely cultured in Dulbecco's Modified Eagle Medium (DMEM; Sigma-Aldrich) supplemented with $2 \mathrm{mM} \mathrm{1-}$ glutamine (Sigma-Aldrich) and 10\% FBS. Briefly, peritoneal macrophages were harvested from three mice, which had been injected intraperitoneally with $3 \mathrm{~mL}$ of thioglycollate broth 3 days before sterile peritoneal lavage with 10 $\mathrm{mL}$ of Hank's balanced salt solution. Cells were grown at $37^{\circ} \mathrm{C}$ in a humidified $5 \% \mathrm{CO}_{2}$ incubator. The cells were allowed to adhere to a 96 -well culture plate at $37^{\circ} \mathrm{C}$ in a $5 \%$ $\mathrm{CO}_{2}$ incubator for $3 \mathrm{~h}$. Cells were grown in RPMI medium supplemented with $10 \%$ heat-inactivated FBS, $100 \mathrm{U} / \mathrm{mL}$ penicillin, and $100 \mu \mathrm{g} / \mathrm{mL}$ of streptomycin. Salmonella typhimurium was grown on Luria-Bertani (LB) agar or in $\mathrm{LB}$ broth, where appropriate, at $37^{\circ} \mathrm{C}$ under aerobic conditions. Mice were housed in specific pathogen-free (SPF) conditions at $21-24^{\circ} \mathrm{C}$ and between 40 and $60 \%$ relative humidity with a $12 \mathrm{~h}$ light-dark cycle. All animals were acclimatized for at least 1 week prior to the start of experiments. All studies were performed in accordance with the guide for animal experimentation by Wonkwang University and approved by the university's institutional animal care and use committee (Approval No. WKU11-21).

\section{Preparation of standardized M. alba L. extract}

Dried fruits of $M$. alba were purchased from a local herbal market in Jeonbuk, Korea. The fruits were pulverized into powder and extracted twice with hot water $\left(80^{\circ} \mathrm{C}\right)$ for $5 \mathrm{~h}$. The solvent was removed under reduced pressure in a RV10 rotary evaporator (IKA, Staufen, Germany) to yield $M$. alba fruit hot water extract $(42.8 \%, w / w)$. The extract was dried to a powder and kept in a closed container until use. To avoid variations in activity for different preparations, sufficient extract was obtained in one batch for use throughout the study. The content of the marker chlorogenic acid in $M$. alba L. was quantitated using high performance liquid chromatography. Results indicated that $M$. alba $\mathrm{L}$. possessed $1.18 \mathrm{mg}$ of chlorogenic acid per $1.0 \mathrm{~g}$ of extract (Fig. 1).

\section{Induction of S. typhimurium infectious model}

SPF male ICR (Institute for Cancer Research) mice (5 weeks old and 25-27 g body weight) were purchased from Hanil Laboratory Animals (Iksan, Korea). The mice were randomly divided into two sets (Fig. 2). The first set contained three groups: a normal group $(n=10), S$. typhimuriuminfected group $(N=10)$, and $500 \mathrm{mg} / \mathrm{kg} /$ day $M$. alba $\mathrm{L} .+$ S. typhimurium-infected group $(n=10)$. The second set contained five groups: a normal group $(n=7) ; S$. typhimuriuminfected group $(N=7) ; 100,300$, and $500 \mathrm{mg} / \mathrm{kg} /$ day $M$. alba L. + S. typhimurium-infected group ( $n=7$, respectively). The normal and $S$. typhimurium-infected groups in these experiments were administered the same volume of distilled water. M. alba L. was dissolved in sterile doubledistilled water and administered for 5 days consecutively. Twenty-four hours after the last drug administration, the mice of the first set were intraperitoneally injected with a lethal dose of bacterial suspension $\left(10^{7}\right.$ colony forming units (CFU)/mouse) to induce peritonitis. The mice in the second set were intraperitoneally injected with a sublethal dose of bacterial suspension ( $10^{5} \mathrm{CFU} /$ mouse) to induce peritonitis. The challenged mice were fed a standard diet and water for 8 days and their survival and health were monitored twice per day throughout the experimental period. Any animal that exhibited severe clinical abnormalities, became moribund, or lost $20 \%$ of its initial body weight was sacrificed by ethyl ether narcosis and exsanguination. At the end of the experiment, the mice were subjected to ether anesthesia. The blood samples were collected from the central vein.

\section{Measurement of cytokines}

Blood and cell culture media were collected and then TNF- $\alpha$, IL-6, IL-12, and IFN- $\gamma$ production was measured by the sandwich ELISA method according to the manufacturer's instructions (R\&D Systems (TNF- $\alpha$; DY410, IL-6; DY406, IL-12; DY419), Minneapolis, MN, USA and BD PharMingen (IFN- $\gamma$; RUO - 558258), CA, USA)).

\section{Hematology test}

Blood samples were collected from the vena cava of all animals under ethyl ether anesthesia at necropsy for hematology. Blood was transferred to a container (EDTA K2; BD Biosciences, South Korea) for WBC (white blood cell), LYM (lymphocyte), MON (monocyte), and NEU (neutrophil) counts using an HORIBA (Edison, NJ, USA). 

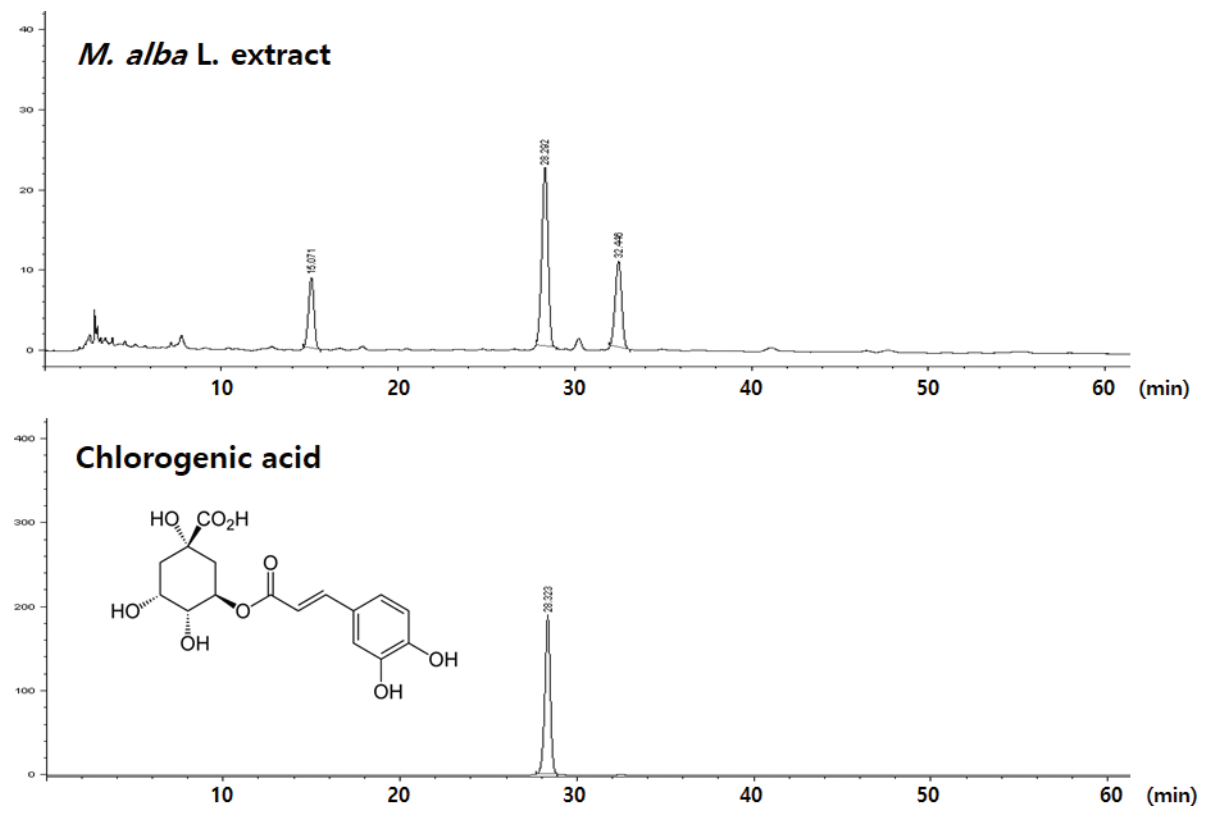

Fig. 1. The structure and high-performance liquid chromatography (HPLC) chromatographic profile of chlorogenic acid in M. alba L. extract at $340 \mathrm{~nm}$.

(a) Lethal dose of pathogen infected model

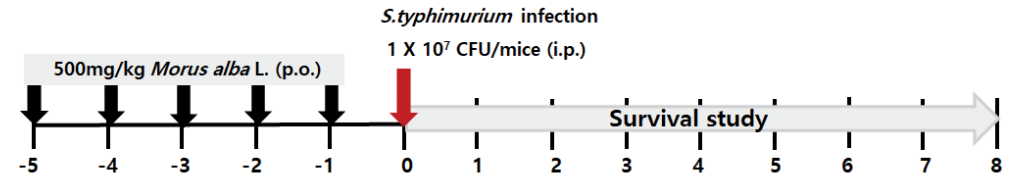

(b) Sub-lethal dose of pathogen infected model

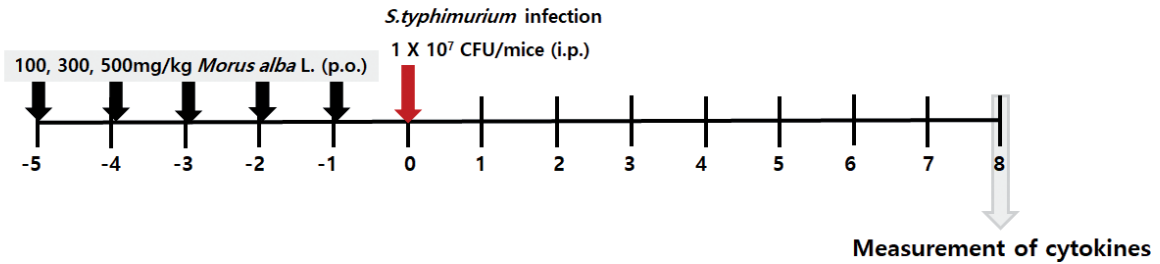

Fig. 2. Time schedule of the experimental procedures.

Assay for peritoneal macrophage phagocytosis

Phagocytosis assays were performed as described by Han et al. (13). Briefly, opsonization of bacteria fluoresceinlabeled Escherichia coli wells were opsonized by incubation for $1 \mathrm{~h}$ at $37^{\circ} \mathrm{C}$ with $5 \%$ complete mouse serum or with $5 \%$ inactivated mouse serum. After opsonization, the serum was removed by centrifugation to eliminate excess opsonins. Fluorescein-5-isothiocyanate (FITC) labeled $E$. coli cells were suspended in Hank's balanced salt solution and added to the adherent phagocytes at a concentration of $5 \times 10^{5} \mathrm{CFU} / \mathrm{mL}$. The final ratios of bacteria to macrophages (multiplicity of infection (MOI) of 50:1) were confirmed in the final volume of $200 \mu \mathrm{L}$. After incubation at $37^{\circ} \mathrm{C}$ for $2 \mathrm{~h}$, phagocytic cells were washed 3 times with phosphate-buffered saline (PBS), which was aspirated to remove non-ingested cell particles. Extracellular fluorescence was quenched by the addition of $100 \mu \mathrm{L}$ of trypan blue. After $1 \mathrm{~min}$, the FITC bacteria that had not been ingested washed away and the macrophages were rinsed twice with PBS. Next, the macrophages were lysed with lysis buffer (10 mM Tris- $\mathrm{HCl}, \mathrm{pH} 7.5,130 \mathrm{mM} \mathrm{NaCl}$, $1 \%$ Triton X-100, $10 \mathrm{mM} \mathrm{Na} \mathrm{HPO}_{4}, 10 \mathrm{mM} \mathrm{Na}_{4} \mathrm{P}_{2} \mathrm{O}_{7}$ ). The fluorescence intensity (relative fluorescence unit) of bacteria inside the cells was determined at excitation 
and emission wavelengths of 480 and $520 \mathrm{~nm}$ by using a spectrofluorometer (Tecan Infinite F200, Männedorf, Switzerland). The relative phagocytic activity was calculated as the percentage of fluorescence intensity in a sample supplemented with FITC bacteria compared with that with no supplementation (control).

\section{Intracellular killing assay}

The intracellular killing assay was conducted as described by Wu et al. (14). RAW264.7 cells were seeded at a density of $5 \times 10^{4}$ cells/well in a 96-well plate containing $200 \mu \mathrm{L}$ complete RAW medium and incubated at $37^{\circ} \mathrm{C}$ for $24 \mathrm{~h}$ in an atmosphere of $5 \% \mathrm{CO}_{2}$. Three colonies of each $S$. typhimurium strain were inoculated into $10 \mathrm{~mL} \mathrm{LB}$ broth with appropriate antibiotics and incubated for $16 \mathrm{~h}$ at $37^{\circ} \mathrm{C}$, with shaking at $200 \mathrm{rpm}$. Cultures were then centrifuged at 3,000 $\mathrm{g}$ for $10 \mathrm{~min}$ and resuspended in complete medium to $5 \times 10^{5} \mathrm{CFU} / \mathrm{mL}$. The culture medium was removed from the RAW264.7 cells and replaced with $200 \mu \mathrm{L}$ of this bacterial inoculum per well, to give a MOI of 10:1. This MOI was used as the frequency of infection and was high enough to enable observation of infection events at the single-cell level in subsequent imaging experiments but minimize Salmonella-induced macrophage death. The cells were then incubated at $37^{\circ} \mathrm{C}$ for $30 \mathrm{~min}$ in an atmosphere of $5 \% \mathrm{CO}_{2}$, after which the supernatant was removed from each well and $200 \mu \mathrm{L}$ complete RAW medium containing $50 \mu \mathrm{g} / \mathrm{mL}$ gentamicin was added; plates were incubated for either $15 \mathrm{~min}(\mathrm{~T} 0)$ or $2 \mathrm{~h}(\mathrm{~T} 2)$ at $37^{\circ} \mathrm{C}$ for $30 \mathrm{~min}$ in an atmosphere of $5 \% \mathrm{CO}_{2}$. The cells were then washed twice with $200 \mu \mathrm{L}$ DMEM and lysed in 1\% saponin, and the number of intracellular bacteria (CFU) was determined by serial dilution and plating on plate count agar. Intracellular killing percentage was calculated as: $[(\mathrm{T} 0-\mathrm{T} 2) / \mathrm{T} 0] \times 100$.

\section{NO assay}

Peritoneal macrophages $\left(1 \times 10^{5}\right.$ cells/well $)$ in a 96 -well plate were incubated in the presence of three concentrations of $M$. alba L. (10, 30, and $100 \mu \mathrm{g} / \mathrm{mL})$ for $24 \mathrm{~h}$. NO was measured by determining the concentration of its stable oxidative metabolite nitrite using a microplate assay according to a described method (10). Supernatants $(100 \mu \mathrm{L})$ were collected and mixed with an equal volume of Griess reagent ( $1 \%$ sulfanilamide and $0.1 \% \mathrm{~N}-(1$ - naphthyl)ethylenediamine dihydrochloride in 5\% phosphoric acid) at room temperature for $15 \mathrm{~min}$. The absorbance was read at $570 \mathrm{~nm}$ using a microplate reader. $\mathrm{NaNO}_{2}$ was used as a standard.

\section{Statistical analysis}

Data are expressed as the mean \pm SD and were examined for their statistical significance of difference by analysis of variance and Student's $t$-test. A $p$-value $<0.05$ was considered statistically significant.

\section{Results}

Effect of M. alba L. on pathogenic S. typhimurium in mice To determine the therapeutic effects of $M$. alba L. on life expectancy, mice were infected with a lethal dose $\left(1 \times 10^{7}\right.$ CFU) of $S$. typhimurium intraperitoneally and assessed for mortality. Figure 3 shows that the mortality rates in the normal and S. typhimurium groups were 100 and $0 \%$ on Day 8. By contrast, the groups treated with M. alba L. showed $60 \%$ had survived on Day 8 . These observations demonstrate the potential of $M$. alba L. to protect mice against the lethal effects of S. typhimurium.

\section{Effects of M. alba L. on body and organ weight}

Body weight was monitored during the experiment to reflect the health status of mice. All the infected groups had significantly greater weight loss compared with normal mice. At Day 5, mice infected with $S$. typhimurium had lost significantly more weight compared with the $M$. alba L. group (Fig. 4). After sacrificing the animals, the organs were removed and weighed. No significant changes in the weights of livers were seen in normal, M. alba L. $+S$. typhimurium, or $S$. typhimurium mice (Table 1). However, spleen weights were significantly increased in animals infected with $S$. typhimurium compared with the normal group. The $M$. alba L. + S. typhimurium group had a significantly higher spleen weight than the $S$. typhimurium group $(p<0.05)$.

\section{Effects of M. alba L. on hematological parameters}

Table 2 shows the effect of $M$. alba L. on the hematological parameters of mice. WBC count was significantly increased in the M. alba L. + S. typhimurium group $(p<0.05)$ compared with the $S$. typhimurium group. Lymphocyte count was decreased in the $M$. alba L. $+S$. typhimurium group and infected control group. Monocyte and neutrophil counts were significantly increased in the $M$. alba L. $+S$. typhimurium group and infected control group compared with the uninfected control group ( $p<0.05$ for all).

\section{Effect of M. alba L. on cytokine production in S. typhimurium-} infected mice

To examine the immunomodulatory effect of $M$. alba L. on pathogenic $S$. typhimurium infection, the mice were administered M. alba L. (100, 300, and $500 \mathrm{mg} / \mathrm{kg}$ ) for 5 days, or were not pretreated and were then challenged with $1 \times 10^{5} \mathrm{CFU} / \mathrm{mouse}$ (sublethal dose) of S. typhimurium. After 8 days, the levels of key immune molecules, IFN- $\gamma$, TNF- $\alpha$, IL-12, and IL- 6 were measured in serum. The mice fed with $M$. alba L. (300 or $500 \mathrm{mg} / \mathrm{kg}$ ) had higher IFN- $\gamma$, IL-12, and TNF- $\alpha$ production compared with the infected group (Fig. 5a, c, d). However, IL-6 production was not significantly different in the serum of mice in all groups (Fig. 5b). 


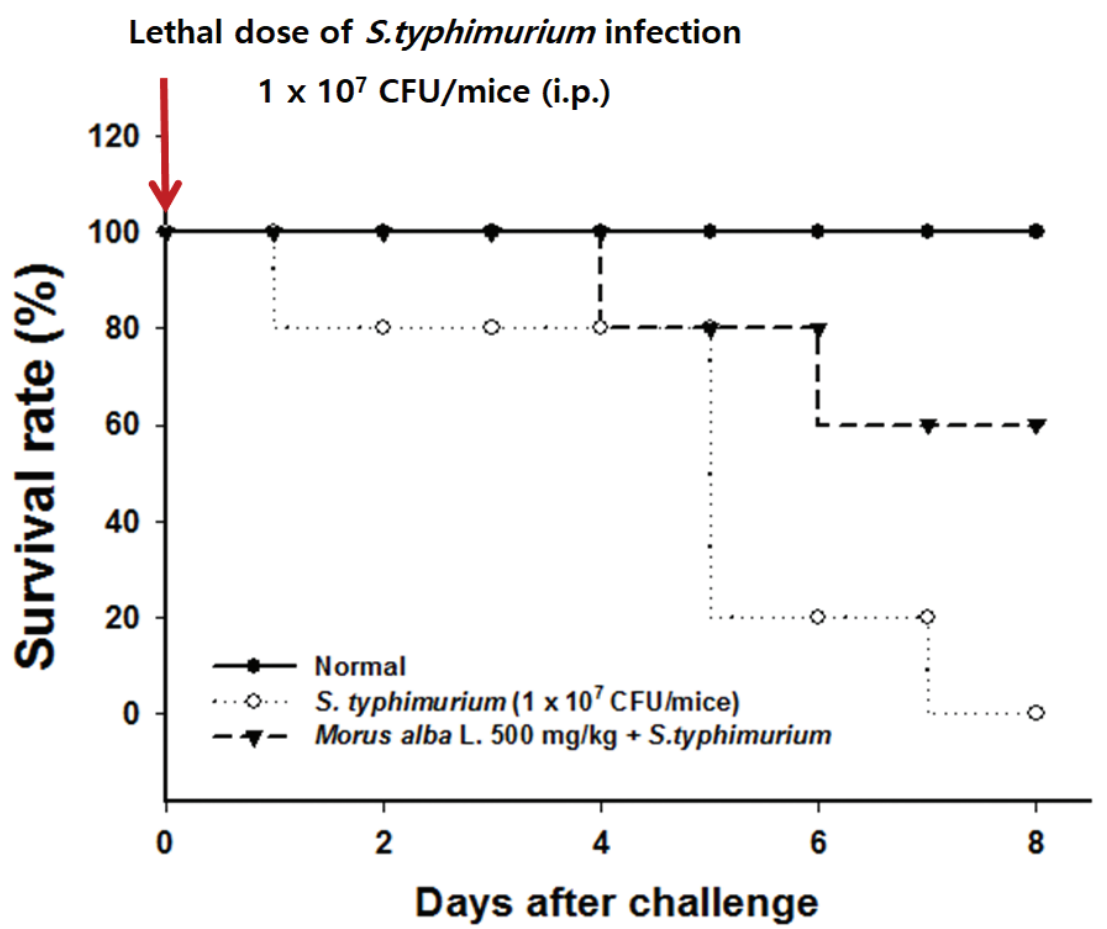

Fig. 3. Effects of M. alba L. on survival rates in mice challenged with pathogenic S. typhimurium. Morus alba L. (500 mg/kg) was orally administered for 5 days to mice, which were then intraperitoneally injected with a lethal dose of a bacterial suspension $\left(10^{7} \mathrm{CFU} / \mathrm{mouse}\right)$ to induce peritonitis. The challenged mice were kept for 8 days on a standard diet with water and their survival was monitored twice a day throughout the experimental period.

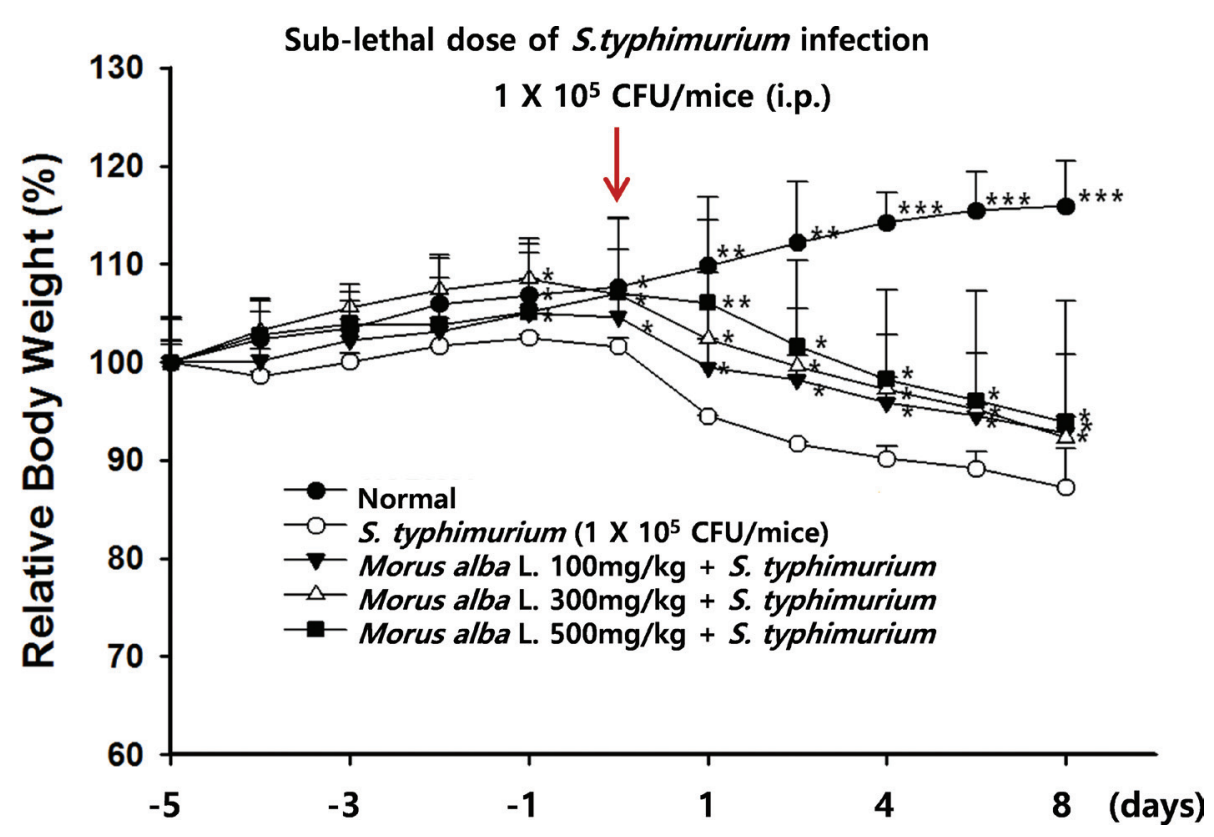

Fig. 4. Effects of M. alba L. on change in body weight in mice challenged with pathogenic S. typhimurium. Morus alba L. (100, 300 , or $500 \mathrm{mg} / \mathrm{kg}$ ) was orally administrated for 5 days to mice, which were then intraperitoneally injected with a sublethal dose of a bacterial suspension $\left(10^{5} \mathrm{CFU} /\right.$ mouse) to induce peritonitis. The body weight was recorded daily. The values are the means \pm S.D. ${ }^{*} p<0.05, * * p<0.01, * * * p<0.001$ compared with the $M$. alba L. group. 
Table 1. Effects of M. alba L. on organ weight in mice challenged with pathogenic $S$. typhimurium. The values are the means \pm S.D. ${ }^{*} p<0.05$, compared with the M. alba L. group

\begin{tabular}{lcccc}
\hline Group & $\begin{array}{c}\text { Dose } \\
(\mathrm{mg} / \mathrm{kg})\end{array}$ & $\begin{array}{c}\text { Body } \\
\text { weight (g) }\end{array}$ & $\begin{array}{c}\text { Relative liver } \\
\text { weight } \\
(\%)\end{array}$ & $\begin{array}{c}\text { Relative } \\
\text { Spleen } \\
\text { weight (\%) }\end{array}$ \\
\hline
\end{tabular}

Normal mice

\begin{tabular}{|c|c|c|c|c|}
\hline Saline & - & $36.0 \pm|.4|$ & $5.46 \pm 0.08$ & $0.35 \pm 0.08$ \\
\hline \multicolumn{5}{|c|}{ Mice infected with S. typhimurium ( $1 \times 10^{5}$ CFU/mouse $)$} \\
\hline Saline & & $25.8 \pm 1.18$ & $6.88 \pm 0.20$ & $1.16 \pm 0.08$ \\
\hline \multirow[t]{3}{*}{ Morus alba L. } & 100 & $27.6 \pm 0.47$ & $7.40 \pm 0.64$ & $1.41 \pm 0.09$ \\
\hline & 300 & $26.4 \pm 2.46$ & $7.91 \pm 0.11$ & $1.55 \pm 0.11$ \\
\hline & 500 & $27.0 \pm 3.57$ & $7.40 \pm 0.93$ & $1.60 \pm 0.04 *$ \\
\hline
\end{tabular}

Effect of M. alba L. on peritoneal macrophage phagocytosis $M$. alba L. at the tested concentrations did not affect cytotoxicity (data not shown). Thus, we treated cells with $M$. alba L. at concentrations of 10,30 , and $100 \mu \mathrm{g} / \mathrm{mL}$ during subsequent experiments. To determine the effects of $M$. alba L. on the phagocytic activity of macrophages, the uptake of FITC-labeled E. coli particles was compared between M. alba L. treated and untreated macrophages. The phagocytosis of macrophages was increased by $M$. alba L. treatment in a dose-dependent manner (Fig. 6a). These results demonstrate that $M$. alba L. enhances macrophage phagocytosis.

\section{Effect of M. alba L. on intracellular killing}

The bacteria defense functions of macrophages were further assessed by using a gentamicin protection assay, a

Table 2. Effects of $M$. alba L. on hematological parameters in mice challenged with pathogenic $S$. typhimurium. The values are the means \pm S.D. * $p<0.05$, compared with the M. alba L. group

\begin{tabular}{|c|c|c|c|c|c|}
\hline Group & Dose (mg/kg) & WBC $\left(10^{3} / \mathrm{ml}\right)$ & LYM (\%) & MON (\%) & NEU (\%) \\
\hline \multicolumn{6}{|l|}{ Normal mice } \\
\hline Saline & - & $4.32 \pm 0.19$ & $76.3 \pm 10.28$ & $18.4 \pm 2.32$ & $6.15 \pm 3.27$ \\
\hline \multicolumn{6}{|c|}{ Mice infected with S. typhimurium ( $1 \times 10^{5} \mathrm{CFU} /$ mouse $)$} \\
\hline Saline & & $1.78 \pm 0.24$ & $61.3 \pm 7.25$ & $23.8 \pm 1.93$ & $16.1 \pm 1.27$ \\
\hline \multirow[t]{3}{*}{ Morus alba L. } & 100 & $1.93 \pm 0.27$ & $62.7 \pm 8.93$ & $25.4 \pm 1.42$ & $13.6 \pm 1.95$ \\
\hline & 300 & $4.22 \pm 0.43 *$ & $55.4 \pm 11.75$ & $29.5 \pm 1.28 *$ & $22.7 \pm 2.95$ \\
\hline & 500 & $5.91 \pm 1.73 *$ & $53.4 \pm 7.32$ & $28.7 \pm 1.15 *$ & $25.1 \pm 1.87 *$ \\
\hline
\end{tabular}

WBC, white blood cells; LYM, lymphocytes; MON, monocytes; NEU, neutrophils.
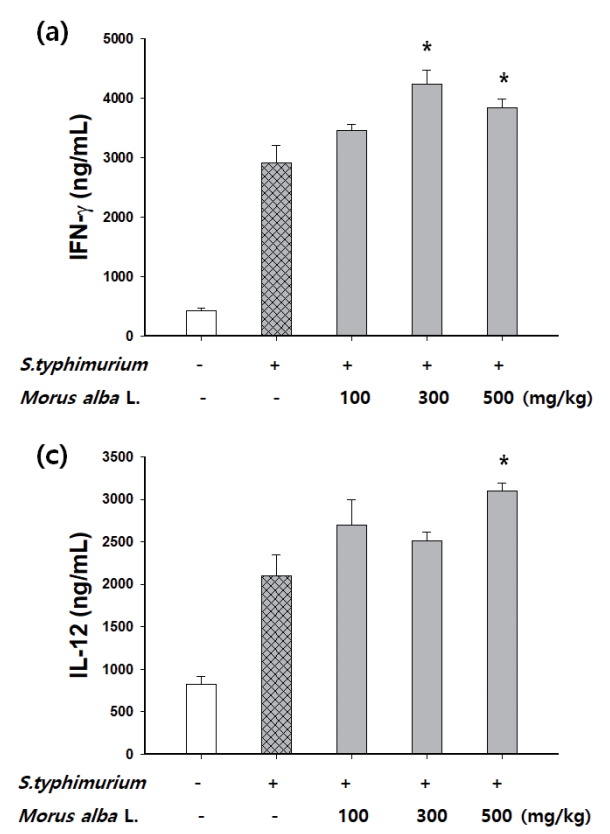
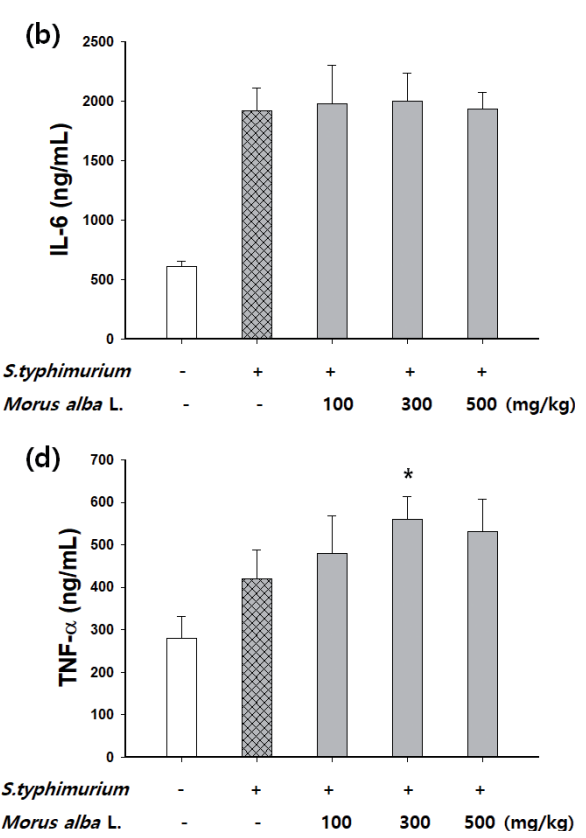

Fig. 5. Effect of M. alba L. on the production of cytokines in mice challenged with pathogenic S. typhimurium. Morus alba L. (100, 300 , or $500 \mathrm{mg} / \mathrm{kg}$ ) was orally administrated for 5 days to mice, which were then intraperitoneally injected with a sublethal dose of a bacterial suspension $\left(10^{5} \mathrm{CFU} /\right.$ mouse $)$ to induce peritonitis. At the end of the experiment, the mice were subjected to ether anesthesia. Serum was collected from the blood of infected mice pre-administered with $M$. alba L. to evaluate the serum levels of (a) IFN- $\gamma$, (b) IL-6, (c) IL-12, and (d) TNF- $\alpha$. The data are the means \pm SD, ${ }^{*} p<0.05$ compared with the $S$. typhimurium group. 
(a)

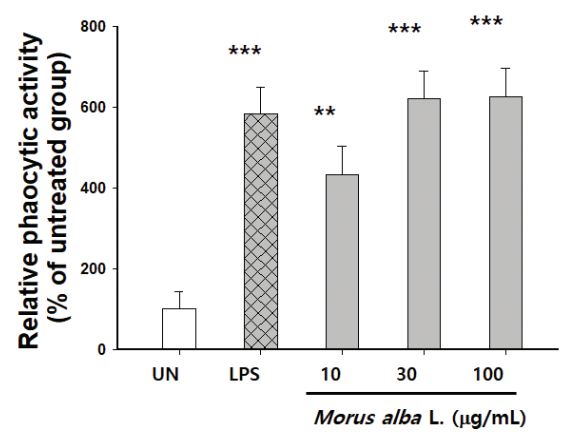

(b)

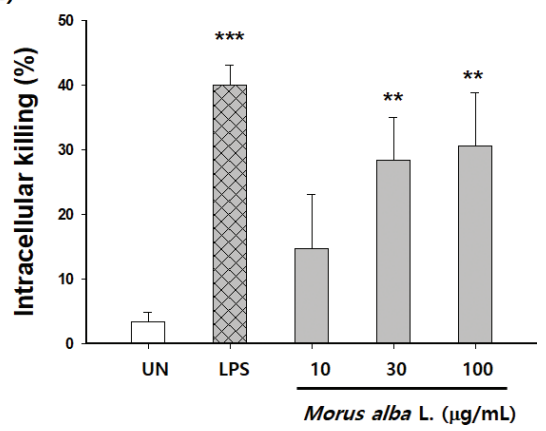

Fig. 6. Effects of $M$. alba L. on phagocytic activity and intracellular killing. Peritoneal macrophages derived from BALB/c mice or RAW 264.7 cells were treated with 10,30 , or $100 \mu \mathrm{g} / \mathrm{mL}$ of $M$. alba L. for $24 \mathrm{~h}$, or with LPS (1 $\mu \mathrm{g} / \mathrm{mL})$ as a positive control. (a) After the addition of FITC-labeled E. coli, the cells were incubated for $2 \mathrm{~h}$. The supernatants containing unphagocytosed bacteria were removed and then lysed with Triton X-100 containing lysis buffer. Fluorescence intensities of the lysed cells were measured by using a fluorescence microplate reader. (b) After the addition of S. typhimurium, the cells were incubated for $2 \mathrm{~h}$. Unphagocytosed bacteria were removed and the cells were lysed with $1 \%$ saponin. The number of intracellular bacteria (CFU) was determined by serial dilution and plating on plate count agar (PCA). The values are the mean \pm S.D. ${ }^{* *} p<0.01, * * *<<$ 0.001 compared with the untreated group.
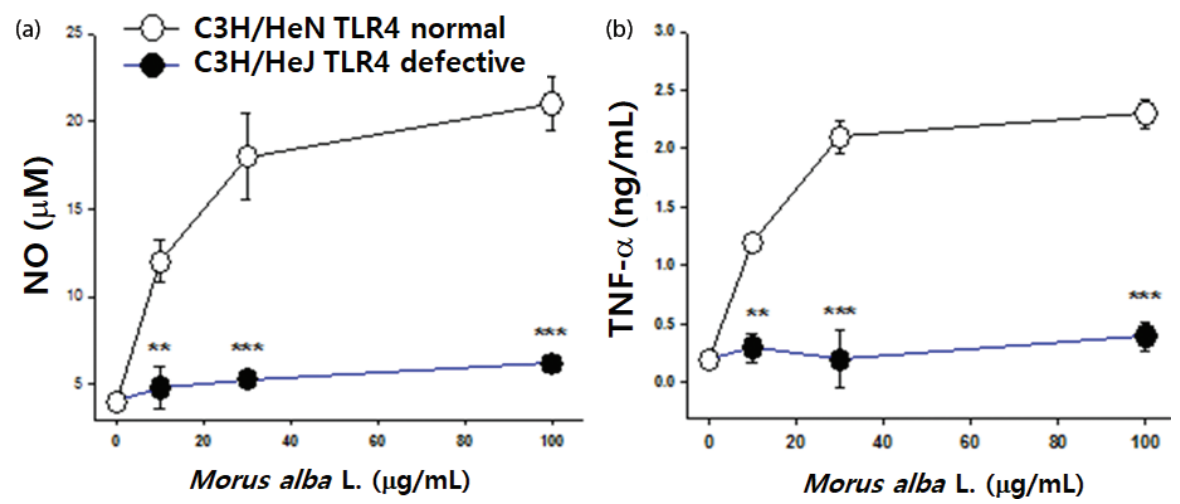

Fig. 7. Effects of $M$. alba L. on peritoneal macrophages derived from $\mathrm{C} 3 \mathrm{H} / \mathrm{HeN}$ and $\mathrm{C} 3 \mathrm{H} / \mathrm{HeJ}$ mice. Peritoneal macrophages from $\mathrm{C} 3 \mathrm{H} / \mathrm{HeN}$ and $\mathrm{C} 3 \mathrm{H} / \mathrm{HeJ}$ mice were stimulated with $M$. alba L. or LPS (1 $\mu \mathrm{g} / \mathrm{mL}$ ) as a positive control for $24 \mathrm{~h}$. (a) NO and (b) $\mathrm{TNF}-\alpha$ levels were determined by ELISA. The values are the means \pm S.D. ${ }^{*} p<0.01, * * * p<0.001$, compared with C3H/HeN mice.

method commonly used to test intracellular bactericidal activity with live Salmonella as the target. The intracellular killing of macrophages was increased by M. alba L. treatment in a dose-dependent manner (Fig. 6b), which demonstrated that $M$. alba L. enhanced macrophage intracellular killing.

\section{Effects of M. alba L. on peritoneal macrophages from TLR4- deficient mice}

To investigate the involvement of TLR4 signaling in mediating the beneficial effects of $M$. alba L., we compared $\mathrm{NO}$ and TNF- $\alpha$ production in peritoneal macrophages from wild-type $(\mathrm{C} 3 \mathrm{H} / \mathrm{HeN})$ or TLR4-deficient mice $(\mathrm{C} 3 \mathrm{H} / \mathrm{HeJ})$. Significantly increased NO and TNF- $\alpha$ was detected in peritoneal macrophages from $\mathrm{C} 3 \mathrm{H} / \mathrm{HeN}$ but not $\mathrm{C} 3 \mathrm{H} / \mathrm{HeJ}$ mice after $M$. alba L. treatment (Fig. 7). Therefore, $M$. alba L. induces the production of proinflammatory cytokines via TLR4.

\section{Discussion}

Morus alba L., white mulberry, is a deciduous tree that belongs to the Moraceae family, which is widely distributed in Asia. M. alba L. has been used worldwide in traditional medicine for the treatment of various diseases from ancient times to the present $(12,15)$. Previous studies have indicated that $M$. alba L. possesses various pharmacological properties, including antimicrobial (16), antioxidant (17), antitumor (18), anti-obesity (19), antihypotensive (20), neuroprotective $(21,22)$, and antidiabetic $(23,24)$ actions. In addition, our previous studies indicated that the extracts and components of $M$. alba L. fruit water extract were safe (25), immunostimulatory $(10,12,26)$, and had indirect anticancer activity by enhancing immune responses mediated by TLR 4 signaling (12). However, the effects and mechanisms involved in pathogen defense actions have remained elusive. Therefore, in this study, we examined the pathogen defense 
properties of $M$. alba L. in mice challenged with pathogenic S. typhimurium.

Several studies have suggested that host cells exposed to different groups of pathogens respond with common transcriptional activation programs, referred to as the core response to infection (27). Macrophages, monocytes, and granulocytes are involved in the non-specific defense mechanism against pathogens. The common response of macrophages to bacterial infections involves the upregulation of genes involved in M1 polarization (28).

We report that $M$. alba L. enhanced immune activity and resistance to experimental challenge with $S$. typhimurium infection. However, $M$. alba $\mathrm{L}$. did not directly kill S. typhimurium. Therefore, the pathogen defense effect of $M$. alba L. is likely to be mediated by potentiation of the host's defense system, such as macrophage activation, rather than by the indirect inhibition of bacterial growth.

We observed hepatomegaly and splenomegaly in $S$. typhimurium infected mice. The present results showed that the killing activity of monocytes and neutrophils was increased in M. alba L. treated mice infected with S. typhimurium, indicating its potential to enhance non-specific immune responses. Systemic Salmonella infection commonly induces splenomegaly in murine or human hosts. The capacity of Salmonella to evade killing and replicate within tissue phagocytes means that infection can quickly overwhelm local host defenses at the site of infection. Thus, inflammatory signals produced by cells in the infected tissue rapidly recruit neutrophils and inflammatory monocytes to engulf replicating bacteria. Splenomegaly can cause splenic structure change; splenic tissue structure is correlated with the recruitment and expansion of $\mathrm{T}$ and B cells and macrophages (29). The present study provides evidence of the induction of the macrophage phagocytic effect by M. alba $\mathrm{L}$.

Furthermore, cytokines such as IL-12, IFN- $\gamma$, and TNF- $\alpha$ have a vital role in both innate and adaptive immunity and are responsible for Th1 polarization $(30,31)$. Because IL-12, IFN- $\gamma$, and TNF- $\alpha$ were upregulated in M. alba $\mathrm{L}$. treated groups, this suggests it has important immunoregulatory activity by activating macrophages. However, Th2 cytokine production (IL-6) was unaffected. IL-12 is produced primarily by monocytes, macrophages, and other antigen-presenting cells and is essential for fighting infectious diseases and cancer. IL-12 synergizes with TNF- $\alpha$ and other proinflammatory cytokines to stimulate IFN- $\gamma$ production, as well $\mathrm{NK}$ and $\mathrm{CD} 8 \mathrm{~T}$ cell cytotoxicity (32). TNF- $\alpha$ is another proinflammatory cytokine and its levels in plasma are directly correlated with the ability of phagocytes to generate superoxide and the activity of iNOS and, thus, NO levels (31). One of the key requirements for the accuracy of the in vitro bactericidal assay is to eliminate the bacteria remaining extracellularly after ingestion by macrophages. For this purpose, gentamicin at a concentration of c. $50 \mathrm{mg} / \mathrm{L}$ has been widely used, as this antibiotic is believed to be incapable of penetrating the macrophage membrane. However, there are reports that such a high concentration of gentamicin penetrates HeLa cells, reaching c. $90 \%$ of the extracellular concentration after incubation for $72 \mathrm{~h}$. The M1, or proinflammatory, macrophage phenotype is characterized by high levels of proinflammatory cytokines and reactive nitrogen and oxygen intermediates, the promotion of a Th1 response, and strong microbicidal and tumoricidal activity. Phagocytosis is the first step in the macrophage response to invading microorganisms and activation of phagocytosis enhances innate immune responses (33). Phagocytosis by macrophages was increased by $M$. alba $\mathrm{L}$. treatment in a dose-dependent manner. The activation of intracellular killing mechanisms is critical to the antimicrobial activity of phagocytes. The pathogen internalization is followed by the fusion of phagosomes and lysosomes, which exposes the internalized pathogen to antimicrobial proteins and reactive molecules. Results indicate that $M$. alba $\mathrm{L}$. is armed with such a killing capacity in a dose-dependent manner.

The first step in the modulation of cellular events is binding to receptors. TLRs play a central role in macrophage activation and the control of pathogen infections (5).

TLR4 is expressed on macrophages, dendritic cells, B cells, T cells, and endothelial cells. The role of TLR as a $M$. alba L. receptor was clearly demonstrated in our previous study $(10,12)$. TLR4 binds with $M$. alba L. activated signaling pathways, including MAPKs and NF-кB. Activation of MAPKs is required for the induction of $\mathrm{NO}$ as it controls the activation of NF-kB. In this study, the role of TLR4 as an M. alba L. receptor was confirmed in macrophages. To investigate this membrane receptor, we examined the effect of $M$. alba $\mathrm{L}$. on primary macrophages isolated from wild-type $\mathrm{C} 3 \mathrm{H} / \mathrm{HeN}$ and $\mathrm{C} 3 \mathrm{H} / \mathrm{HeJ}$ mice that have mutant TLR4. Morus alba $\mathrm{L}$. induced NO production and TNF- $\alpha$ in macrophages from $\mathrm{C} 3 \mathrm{H} / \mathrm{HeN}$, but not from TLR4 mutated C3H/HeJ mice, which suggests that TLR4 is the membrane receptor for M. alba $\mathrm{L}$.

In summary, our data suggest that $M$. alba $\mathrm{L}$. activated macrophages via TLR4 to provide protection against $\mathrm{Sal}$ monella infection, indicating that $M$. alba L. modulates the effector functions of immunocompetent cells.

\section{Acknowledgements}

This work was supported by the Industrial Core Technology Development Program (10067293), funded by the Ministry of Trade, Industry, and Energy (MOTIE, South Korea).

\section{Authors' contributions}

All authors read and approved the final version of the manuscript. S.Y.K. conceived and designed the experiments. B.Y.C. and H.C.L. performed the experiments. B.Y.C., J.S.O., and S.Y.K. analyzed the 
data. S.Y.K. and B.Y.C. drafted the manuscript. B.Y.C., B.S.K., H.C.L., J.S.O., and S.Y.K. revised the manuscript.

\section{Conflicts of interest and funding}

The authors declare that they have no competing interests.

\section{References}

1. Qu Y, Li R, Jiang M, Wang X. Sucralose increases antimicrobial resistance and stimulates recovery of Escherichia coli mutants. Curr Microbiol 2017; 74(7): 885-8. doi: 10.1007/ s00284-017-1255-5.

2. Cherazard R, Epstein M, Doan TL, Salim T, Bharti S, Smith MA. Antimicrobial resistant Streptococcus pneumoniae: prevalence, mechanisms, and clinical implications. Am J Ther 2017; 24(3): e361-9. doi: 10.1097/mjt.0000000000000551.

3. Shaker MA, Shaaban MI. Formulation of carbapenems loaded gold nanoparticles to combat multi-antibiotic bacterial resistance: in vitro antibacterial study. Int J Pharm 2017; 525(1): 71-84. doi: 10.1016/j.ijpharm.2017.04.019.

4. Luo A, Leach ST, Barres R, Hesson LB, Grimm MC, Simar D. The microbiota and epigenetic regulation of $\mathrm{T}$ helper 17/regulatory T cells: in search of a balanced immune system. Front Immunol 2017; 8: 417. doi: 10.3389/fimmu.2017.00417.

5. McClure R, Massari P. TLR-dependent human mucosal epithelial cell responses to microbial pathogens. Front Immunol 2014; 5: 386. doi: 10.3389/fimmu.2014.00386.

6. Gomes MT, Campos PC, de Almeida LA, Oliveira FS, Costa MM, Marim FM, et al. The role of innate immune signals in immunity to Brucella abortus. Front Cell Infect Microbiol 2012; 2: 130. doi: 10.3389/fcimb.2012.00130.

7. Fieber C, Kovarik P. Responses of innate immune cells to group A Streptococcus. Front Cell Infect Microbiol 2014; 4: 140. doi: 10.3389/fcimb.2014.00140.

8. Brito de Assis A, Dos Santos C, Dutra FP, de Oliveira Motta A, Costa FS, Navas CA, et al. Assessing antibacterial potential of components of Phyllomedusa distincta skin and its associated dermal microbiota. J Chem Ecol 2016; 42(2): 139-48. doi: 10.1007/s10886-016-0665-3.

9. Zheng Z, Wei C, Guan K, Yuan Y, Zhang Y, Ma S, et al. Bacterial E3 Ubiquitin Ligase IpaH4.5 of Shigella flexneri targets TBK1 to Dampen the host antibacterial response. J Immunol 2016; 196(3): 1199-208. doi: 10.4049/jimmunol.1501045.

10. Yang XY, Park GS, Lee MH, Chang IA, Kim YC, Kim SY, et al. Toll-like receptor 4-mediated immunoregulation by the aqueous extract of Mori Fructus. Phytother Res 2009; 23(12): 1713-20. doi: $10.1002 / p t r .2818$.

11. Kim SB, Chang BY, Jo YH, Lee SH, Han SB, Hwang BY, et al. Macrophage activating activity of pyrrole alkaloids from Morus alba fruits. J Ethnopharmacol 2013; 145(1): 393-6. doi: 10.1016/j.jep.2012.11.007.

12. Chang BY, Kim SB, Lee MK, Park H, Kim SY. Improved chemotherapeutic activity by Morus alba fruits through immune response of toll-like receptor 4. Int J Mol Sci. 2015; 16(10): 24139-58. doi: 10.3390/ijms161024139.

13. Han EH, Choi JH, Hwang YP, Park HJ, Choi CY, Chung YC, et al. Immunostimulatory activity of aqueous extract isolated from Prunella vulgaris. Food Chem Toxicol 2009; 47(1): 62-9. doi: 10.1016/j.fct.2008.10.010.

14. Wu J, Pugh R, Laughlin RC, Andrews-Polymenis H, McClelland M, Bäumler AJ, et al. High-throughput assay to phenotype Salmonella enterica typhimurium association, invasion, and replication in macrophages. J Vis Exp 2014; 11(90): e51759. doi: $10.3791 / 51759$.

15. Choi JW, Synytsya A, Capek P, Bleha R, Pohl R, Park YI. Structural analysis and anti-obesity effect of a pectic polysaccharide isolated from Korean mulberry fruit Oddi (Morus alba L.). Carbohydr Polym 2016; 146: 187-96. doi: 10.1016/j. carbpol.2016.03.043.

16. Tirupathi RG, Suresh BK, Ujwal KJ, Sujana P, Raoa AV, Sreedhar AS. Anti-microbial principles of selected remedial plants from Southern India. Asian Pac J Trop Biomed 2011; 1(4): 298 305. doi: 10.1016/s2221-1691(11)60047-6.

17. Kujawska M, Ewertowska M, Adamska T, Ignatowicz E, Flaczyk E, Przeor M, et al. Protective effect of Morus alba leaf extract on N-Nitrosodiethylamine-induced Hepatocarcinogenesis in rats. In vivo 2016; 30(6): 807-12.

18. Yang Y, Zhang T, Xiao L, Yang L, Chen R. Two new chalcones from leaves of Morus alba L. Fitoterapia. 2010; 81(6): 614-16. doi: 10.1016/j.fitote.2010.03.005.

19. Vick SJ, Bovet D, Anderson JR. How do African grey parrots (Psittacus erithacus) perform on a delay of gratification task? Anim Cogn 2010; 13(2): 351-8. doi: 10.1007/ s10071-009-0284-2.

20. Lee YJ, Choi DH, Kim EJ, Kim HY, Kwon TO, Kang DG, et al. Hypotensive, hypolipidemic, and vascular protective effects of Morus alba L. in rats fed an atherogenic diet. Am J Chin Med 2011; 39(1): 39-52. doi: 10.1142/s0192415x11008634.

21. Jung JW, Ko WM, Park JH, Seo KH, Oh EJ, Lee DY, et al. Isoprenylated flavonoids from the root bark of Morus alba and their hepatoprotective and neuroprotective activities. Arch Pharm Res 2015; 38(11): 2066-75. doi: 10.1007/s12272-015-0613-8.

22. Seo KH, Lee DY, Jeong RH, Lee DS, Kim YE, Hong EK, et al. Neuroprotective effect of prenylated arylbenzofuran and flavonoids from morus alba fruits on glutamate-induced oxidative injury in HT22 hippocampal cells. J Med Food 2015; 18(4): 403-8. doi: 10.1089/jmf.2014.3196.

23. Jiao Y, Wang X, Jiang X, Kong F, Wang S, Yan C. Antidiabetic effects of Morus alba fruit polysaccharides on high-fat diet- and streptozotocin-induced type 2 diabetes in rats. J Ethnopharmacol 2017; 199: 119-27. doi: 10.1016/j.jep.2017.

24. Ye M, Ke Y, Liu B, Yuan Y, Wang F, Bu S, et al. Root bark of Morus alba ameliorates the depressive-like behaviors in diabetic rats. Neurosci Lett 2017; 637: 136-41. doi: 10.1016/j. neulet.2016.11.036.

25. Chang BY, Kim SB, Lee MK, Park H, Kim SY. Nonclinical safety assessment of Morus alba L. fruits: study of 90-D toxicity in Sprague Dawley Rats and genotoxicity in Salmonella. J Food Sci 2016; 81(5): T1328-35. doi: 10.1111/1750-3841.13285.

26. Kim SB, Chang BY, Hwang BY, Kim SY, Lee MK. Pyrrole alkaloids from the fruits of Morus alba. Bioorg Med Chem Lett 2014; 24(24): 5656-9. doi: 10.1016/j.bmcl.2014.10.073.

27. Hurley D, McCusker MP, Fanning S, Martins M. Salmonella-host interactions - modulation of the host innate immune system. Front Immunol 2014; 5: 481. doi: 10.3389/ fimmu.2014.00481.

28. Zhou D, Yang K, Chen L, Zhang W, Xu Z, Zuo J, et al. Promising landscape for regulating macrophage polarization: epigenetic viewpoint. Oncotarget. 2017; 8(34): 57693-706. doi: 10.18632/oncotarget.17027.

29. Chu HB, Zhang TG, Zhao JH, Jian FG, Xu YB, Wang T, Wang M, Tang JY, Sun HJ, Li K, Guo WJ, Zhu XJ. Assessment of immune cells and function of the residual spleen after subtotal splenectomy due to splenomegaly in cirrhotic patients. BMC immunology 2014; 15: 42. doi:10.1186/s12865-014-0042-3 
30. Kalupahana RS, Mastroeni P, Maskell D, Blacklaws BA. Activation of murine dendritic cells and macrophages induced by Salmonella enterica serovar Typhimurium. Immunology 2005; 115(4): 462-72. doi: 10.1111/j.1365-2567.2005.02180.x.

31. Perkins DJ, Rajaiah R, Tennant SM, Ramachandran G, Higginson EE, Dyson TN, et al. Salmonella typhimurium co-opts the host type I IFN system to restrict macrophage innate immune transcriptional responses selectively. J Immunol. 2015; 195(5): 2461-71. doi: 10.4049/jimmunol.1500105.

32. Fernandez-Cabezudo MJ, Mechkarska M, Azimullah S, al-Ramadi BK. Modulation of macrophage proinflammatory functions by cytokine-expressing Salmonella vectors. Clin Immunol 2009; 130(1): 51-60. doi: 10.1016/j. clim.2008.08.017.

33. Hamidzadeh K, Mosser DM. Purinergic signaling to terminate TLR responses in macrophages. Front Immunol 2016; 7: 74. doi: 10.3389/fimmu.2016.00074.

\section{*SungYeon Kim}

Institute of Pharmaceutical Research and Development College of Pharmacy Wonkwang University Iksan, Jeonbuk 54538 South Korea

Email: sungykim@wonkwang.ac.kr 